\title{
Pengaruh Audit Tenure dan Financial Distress pada Audit Delay dengan Spesialisasi Auditor Sebagai Variabel Pemoderasi
}

\author{
Ni Made Dwi Candra Sawitri ${ }^{1}$ \\ I Ketut Budiartha ${ }^{2}$
}

${ }^{1}$ Fakultas Ekonomi dan Bisnis Universitas Udayana, Bali, Indonesia email:candrasawitri02@gmail.com/Telp: +62 89686583528

${ }^{2}$ Fakultas Ekonomi dan Bisnis Universitas Udayana, Bali, Indonesia

\begin{abstract}
ABSTRAK
Tujuan dari penelitian ini adalah untuk menganalisis spesialisasi auditor memoderasi pengaruh audit tenure dan financial distress pada audit delay pada perusahaan pertambangan di Di Bursa Efek Indonesia tahun 2012-2016. Sampel ditentukan menggunakan metode purposive sampling. Populasi penelitian ini berjumlah 42 perusahaan. Meneliti sebanyak 25 perusahaan dari 32 perusahaan yang termasuk dalam sampel. Penelitian ini menggunakan teknik analisis data uji Moderating Regression Analysis (MRA). Hasil penelitian ini yaitu spesialisasi auditor tidak memoderasi pengaruh audit tenure pada audit delay. Spesialisasi auditor memperlemah pengaruh financial distress pada audit delay. Audit tenure tidak berpengaruh pada audit delay. Financial distress berpengaruh positif pada audit delay. Kata Kunci : Audit tenure, financial distress, audit delay, spesialisasi auditor
\end{abstract}

\begin{abstract}
The purpose of this research is to analyze the auditor specialization to moderate the influence of audit of tenure and financial distress on audit delay at mining company in Indonesia Stock Exchange year 2012-2016. The sample is determined using purposive sampling method. The population of this study amounted to 42 companies. Researched as many as 25 companies from 32 companies included in the sample. This research uses technique of data analysis of Moderating Regression Analysis (MRA) test. The result of this research is that the auditor specialization does not moderate the influence of audit audit on audit delay. Specialization of auditors weakens the influence of financial distress on audit delay. Tenure audit has no effect on audit delay. Financial distress positively affects the audit delay.

Keywords : Audit tenure, financial distress, audit delay, auditor specialization
\end{abstract}

\section{PENDAHULUAN}

Indonesia saat ini perkembangan perusahaan semakin pesat. Kualitas perusahaan dapat dinilai dari penyajian laporan keuangan. Dalam menjalankan fungsi pasar modal, laporan keuangan merupakan aspek penting (Owusu, 2006). Ketepatan waktu penyusunan laporan keuangan berpengaruh pada nilai laporan keuangan tersebut. Berbagai kendala dialami perusahaan untuk menyajian laporan keuangan 
Ni Made Dwi Candra Sawitri dan I Ketut Budiartha. Pengaruh ...

secara tepat waktu. Keharusan dimana laporan keuangan untuk diaudit oleh auditor untuk memberikan opini mengenai kewajaran suatu laporan keuangan merupakan salah satu kendala yang dialami perusahaan. Munculnya audit delay yang panjang disebabkan karena keinginan perusahaan yang berusaha untuk memperbaiki laporan keuangan agar menghasilkan suatu laporan yang memiliki kualitas yang tinggi.

Audit delay yang panjang dapat terjadi dikarenakan proses perbaikan suatu laporan keuangan membutuhkan waktu yang lama. Auditor membutuhkan waktu yang semakin panjang dalam menjalankan proses audit dikarenakankerugian yang dialami perusahaan. Kerugian tersebut merupakan salah satu faktor yang mempengaruhi terjadinya Audit delay (Carslaw \& Kaplan, 1991). Audit delay adalah lamanya waktu penyelesaian audit yang diukur dari tanggal penutupan tahun buku hingga tanggal diselesaikannya pekerjaan lapangan oleh auditor independen (Hersugondo, 2013). Semakin lama auditor dalam menyelesaikan pekerjaan auditnya maka semakin panjang audit delay (Dewi, 2013).

Ketepatan waktu perusahaan dalam mempublikasikan laporan keuangan kepada masyarakat umum tergantung dari ketepatan waktu seorang auditor dalam menyelesaikan pekerjaan auditnya. Halim (2000) menyebutkan bahwa ketepatan waktu penyajian laporan keuangan dan laporan audit menjadi prasyarat utama bagi peningkatan harga saham perusahaan tersebut. Perusahaan diharapkan mampu mengendalikan terjadinya audit delay, untuk mengatasi reaksi pasar pada nilai perusahaan. Setiap emiten dan perusahaan publik yang terdaftar di Bursa Efek Indonesia wajib menyampaikan laporan keuangan tahunan kepada OJK. 
Ketepatan penyampaian suatu laporan keuangan diatur dalam peraturan Otoritas Jasa Keuangan Nomor 29/POJK.04/2016.

Fenomena yang berkaitan dengan audit delay yakni dibalik melesatnya laju harga saham di pasar modal, namun menyisakan masalah berupa tingkat kedisiplinan emiten dalam mempublikasikan laporan keuangan yang tidak tepat waktu dan tidak sesuai dari ketentuan pihak Bursa Efek Indonesia (BEI). Beberapa pelanggaran emiten terkait pelanggaran laporan keuangan antara lain keterlambatan penyampaian laporan keuangan. Salah satu kasus yang terjadi dimana perusahaan tambang batubara milik Grup Bakrie, PT Bumi Resources Tbk (BUMI) menyatakan belum bisa mengeluarkan laporan keuangan tahunan 2014 karena perseroan masih berjibaku dengan perhitungan utang (www.cnnindonesia.com). Fenomena keterlambatan informasi laporan keuangan seperti kasus PT Bumi Resources Tbk ini menyebabkan munculnya reaksi negatif dari pelaku pasar modal yang menyebabkan kepercayaan investor menurun dan berpengaruh terhadap harga jual saham.

Ketepatan waktu penyampaian laporan keuangan perusahaan publik ini, banyak diteliti dan berkembang baik di Indonesia maupun di negara-negara lain. Masa perikatan ini merupakan salah satu faktor yang dapat mempengeruhi terjadinya audit delay. Definisi audit tenure menurut Geiger dan Rughunandan (2002) adalah lamanya hubungan auditor dan klien yang diukur dengan jumlah tahun. Anggapan bahwa pengetahuan yang lebih mengenai bisnis klien akan diperoleh dengan tenure yang lebih panjang. Giri (2010) menyatakan bahwa 
Ni Made Dwi Candra Sawitri dan I Ketut Budiartha. Pengaruh ...

pengetahuan lebih yang dimiliki auditor dapat mempermudah auditor dalam penyusunan program audit sehingga proses audit menjadi lebih cepat.

Lamanya penugasan auditor pada perusahaan klien memberi pengetahuan bisnis pada auditor sehingga mampu mendesain program audit untuk menghasilkan laporan keuangan yang berkualitas tinggi. Masa perikatan yang lama dan diaudit oleh auditor eksternal yang sama melakukan proses audit dengan klien dapat menciptakan kedekatan antara keduanya yang diduga memberikan kesempatan bagi auditor untuk mengulur waktu penyelesaian audit (Wiguna, 2012). Ketika auditor mampu untuk menjaga indepedensinya maka kedekatan hubungan antara auditor dan klien ini dapat dihindari. Penjelasan tersebut mengartikan bahwa audit tenure atau masa perikatan audit turut memengaruhi kecepatan publikasi dari suatu laporan keuangan auditan.

Penelitian Rustiarini dan Sugiarti (2013) mendapat hasil negatif dan signifikan pengaruh audit tenure terhadap penyampaian informasi laporan keuangan. Berbeda dengan hasil penelitian Fitriyani et al., (2015), Wiguna (2012) yang menyatakan adanya pengaruh positif dan signifikan audit tenure terhadap audit report lag. Pengetahuan KAP akan bertambah mengenai bisnis dan karakteristik perusahaan klien ketika masa perikatan yang panjang (Giri, 2010). Audittenure dapat meningkatkan pemahaman dan pengalaman dalam mempelajarikarakteristik perusahaan Chi dan Huang (2004) dalam Rohami et al (2009).

Kondisi dimana suatu perusahaan mengalami kesulitan keuangan ataupun krisis keuangan, kondisi tersebutlah yang dinamakan Financial distress. Penyebab 
terjadinya penundaan tersebut adalah adanya berita buruk dalam laporan keuangan berupa kesulitan keuangan (financial distress). Perusahaan mengalami kesulitan keuangan akan berdampak terhadap bertambah panjangnya audit delay dikerenakan kondisi perusahaan yang sedang kesulitan keuangan cenderung memiliki risiko audit yang tinggi sehingga meningkatkan waktu auditor untuk meninjau ulang akun-akun laporan keuangan (Ika dan Ghazali, 2012).

Kondisi financial distress pada perusahaan dapat dilihat dari perbandingan hutang jangka panjang dan total aset yang dimiliki perusahaan (Saleh, 2004). Hasil penelitian Mardyana (2014) dan Muliantari dan yenni (2017) menghasilkan bahwa financial distress berpengaruh pada audit delay sedangkan penelitian yang berbeda dilakukan oleh Julien (2013) yang menyatakan bahwa financial distress tidak berpengaruh signidikan terhadap audit report lag.

Berdasarkan beberapa penelitian yang terdahulu yang telah diuraikan pada latar belakang menunjukkan hasil yang tidak konsisten yang menguji pengaruh audit tenure dan financial distress pada audit delay menimbulkan dugaan adanya variabel pemoderasi hubungan variabel tersebut. Jangka waktu tenure yang panjang dan tidak adanya kesulitan keuangan yang dialami oleh suatu perusahaan akan memperpendek terjadinya audit delay dikarenakan auditor sudah lebih mengenali karakteristik dari klien. Hal ini akan lebih di dukung apabila auditor tersebut memiliki predikat sebagai auditor yang spesialis. Auditor yang telah mengikuti pelatihan berfokus pada industri tertentu dan memiliki banyak pengalaman dalam melakukan proses audit yang terkonsentrasi pada satu bidang industri dapat disebut sebagai auditor (Solomon, Shields, \& Whittington, 1999). 
Ni Made Dwi Candra Sawitri dan I Ketut Budiartha. Pengaruh ...

Craswell et al. (1995) menunjukkan bahwa spesialisasi auditor pada bidang tertentu merupakan dimensi dari kualitas audit. Auditor dengan peringkat spesialis mampu memberikan kualitas audit lebih tinggi (Hogan and Jeter, 1999). Habib \& Bhuiyan (2011) auditor dengan peringkat spesialis mampu untuk memulai dan menyelesaikan proses audit lebih cepat dibanding dengan tidak spesialis.

Untuk melakukan penelitian lebih lanjut dengan mereplikasi penelitian dari Yulia dan Rasmini pada tahun 2016. Perbedaan penelitian ini dengan penelitian yang dilakukan oleh Yulia dan Rasmini adalah 1). Penelitian ini menggunakan perusahaan pertambangan dikarenakan perusahaan sektor pertambangan sering mengalami keterlambatan dalam menerbitkan laporan keuangan hingga berujung pada suspensi saham oleh BEI. Keterlambatan perusahaan pertambangan dalam menyampaikan laporan keuangan cenderung dikarenakan perusahaan kesulitan dalam penghitungan stocksedangkan pada penelitian sebelumnya menggunakan perusahaan consumer goods. 2). Penelitian ini menghilangkan variabel dependen pergantian auditor. 3). Tahun yang digunakan dalam penetilian ini menggunakan times series yakni tahun 2012-2016 sedangkan penelitian sebelumnya tahun 20092014. 4). Penelitian ini mereplikasi penelitian sebelumnya dengan menambahkan spesialisasi auditor sebagai variabel pemoderasi.

Berdasarkan pemaparan latar belakang tersebut, maka dapat dirumuskan beberapa pokok masalah yakni : bagaimana pengaruh audit tenure dan financial distress pada audit delay. Bagaimana spesialisasi auditor memoderasi pengaruh audit tenure dan financial distress pada audit delay. Tujuan penelitian ini untuk mengetahui pengaruh audit tenure dan financial distress pada audit delay dan 
spesialisasi memoderasi pengaruh audit tenure dan financial distress pada audit delay. Manfaat teoritis penelitian ini adalah dapat memberikan tambahan informasi mengenai bagaimana spesialisasi auditor memoderasi pengaruh audit tenure dan financial distress pada audit delay. Manfaat praktis hasil penelitian ini yaitu dapat dijadikan pedoman dalam melaksanakan audit dengan mengetahui fakotr-faktor yang dapat memengaruhi audit delay.

Menurut Jensen dan Meckling (1976) dalam Febrianty (2011) menyatakan munculnya hubungan agensi ketika principal mempekerjakan agenuntuk memberikan suatu jasa dan mendelegasikan wewenang pengambilan keputusan kepada agen tersebut. Pendesainan suatu kontrak yang tepat guna menyamakan atau menyelaraskan kepentikan antara principal dan agen dalam hal terjadnya konfik klepentingan. Dalam kaitannya dengan teori agensi dengan audit delay keduanya memiliki hubungan yang sangat erat. Dimana audit delay berhubungan dengan ketepatan pempublikasian laporan keuangan, sebab manfaat dari laporan keuangan akan berkurang bila tidak disampaiakan dengan tepat waktu dan tidak akan dapat menambah nilai perusahaan.

Ketepatan waktu penyampaian laporan keuangan berhubungan dengan tempo penyampaian informasi yang disajikan, nilai dari informasi dapat berkurang apabila informasi tidak tersedia tepat waktu. Nilai informasi yang berkurang dapat menyebabkan terjadinya asimetri informasi, dimana asimetri informasi merupakan elemen dari teori keagenan. Untuk dapat mengurangi asimetri informasi, dapat dilakukan dengan penyampaian informasi yang tepat yang dalam hal ini adalah laporan keuangan oleh auditor. 
Ni Made Dwi Candra Sawitri dan I Ketut Budiartha. Pengaruh ...

Perusahaan yang mempublikasikan laporan keuangan akan memberikan informasi kepada pasar dan diharapkan pasar dapat merespon informasi sebagai suatu sinyal yang baik atau buruk. Cara pemberian sinyal dari perusahaan pada pengguna laporan keuangan dikemukakan dalam teori sinyal. Jika sinyal yang diberikan oleh perusahaan merupakan berita baik, maka cenderung menaikkan harga saham perusahaan. Namun sebaliknya, jika sinyal berindikasi pada berita buruk tentu berdampak pada penurunan harga saham perusahaan. Oleh karenanya, sinyal yang diberikan oleh perusahaanmerupakan hal penting bagi investor dalam pengambilan keputusan (Febrianty, 2011).

Teori ini sangat bermanfaat dalam memberikan keakurasian informasi laporan keuangan ke publik yang bermanfaat dalam kebutuhan untuk pembuatan keputusan dari investor. Informasi menjadi kurang relevan saat semakin lama audit report lag karena kurangbergunanya informasi dalam pengambilan keputusan.

Penyelesaian proses audit yang panjang, mengakibat dibutuhkannya waktu bagi auditor dalam memahami karakteristik perusahaan. Dalam penelitian Lee et al. (2009) menemukan bahwa audit tenure yang panjang terkait dengan efisiensi audit yang lebih tinggi, sehingga menghasilkan audit delay yang lebih singkat. Auditor yang memiliki masa perikatan lebih pendek belum memiliki wawasan mengenai karakteristik perusahaan, sehingga akan berdampak pada meningkatnya potensi kegagalan audit yang dapat mengakibatkan bertambahnya durasi audit delay. 
Penelitian Ratnaningsih dan Dwirandra (2016) menyatakanadanya pengaruh negatif dan signifikan audit tenure pada audit delay. Sejalan dengan penelitian yang dilakukan olehDao dan Pham (2014) menunjukan bahwa audit tenure berhubungan negatif dengan audit report lag (ARL). Perikatan audit yang panjang maka pemahaman auditorpada karakteristik perusahaan semakin memadai, hal tersebut dapat menghasilkan audit delay yang lebih pendek. Berdasarkan uraian tersebut diatas, maka dalam penelitian ini diajukan hipotesis sebagai berikut.

$\mathrm{H}_{1}$ : Audit Tenure berpengaruh negatif terhadap Audit delay.

Financial distress merupakan kondisi dimana perusahaan sedang menghadapi masalah kesulitan keuangan dapat diketahui dari ketidakmampuan perusahaan dalam membayar kewajibannya (Agus dan Yadnyana (2017). Situasi yang menggambarkan financial distress yakni kebangkrutan, kegagalan serta ketidakmampuan perusahaan dalam melunasi hutang. Ciri-ciri suatu perusahaan mengalami financial distress adanya perubahan yang signifikan pada komposisi asset dan kewajiban dimana muncul perbandingan nilai yang tinggi antara asset dengan hutang. Jika financial distress terjadi, maka akan berdampak terhadap semakin besarnya resiko yang akan dialami oleh perusahaan.

Meningkatnya resiko ini dapat berberakibat pada semakin panjangnya audit delay karena auditor harus melakukan pemeriksaan risiko sebelum menjalankan proses audit dan berdampak terhadap lamanya proses audit.Penelitian Muliantari dan yenni (2017) menyatakan bahwa financial distress berpengaruh pada audit delay. Perusahaan dianggap sedang mengalami kesulitan keuangan ketika semakin tinggi nilai rasio financial distress. Financial distress yang semakin tinggi pada 
Ni Made Dwi Candra Sawitri dan I Ketut Budiartha. Pengaruh ...

perusahaan akan menyebabkan audit delay yang panjang, sedangkan audit delay akan semakin pendek saat financial distress rendah. Berdasarkan uraian tersebut diatas, maka hipotesis dalam penelitian ini sebagai berikut.

$\mathrm{H}_{2}$ : Financial distress berpengaruh positif terhadap Audit delay.

Auditor dengan spesialisasi dianggap dapat menyelesaikan audit lebih cepat dari auditor non spesialisasi, karena auditor spesialisasi memiliki efisiensi audit. Kwon et al., (2007) menyatakan kualitas audit dapat meningkat apabila auditor spesialisasi industri memiliki kemampuan dalam bidang teknologi, memahami sistem organisasi dan personel. Auditor spesialis memiliki pengetahuan yang lebih spesifik pada industri tertentu lebih unggul jika dibandingkan dengan auditor non-spesialisas, sehingga mampu mendeteksi salah saji material dalam laporan keuangan.

Auditorspesialisasi industri dapat meminimalkan adanya manajemen laba dengan demikian proses audit menjadi lebih efektif dan audit dengan kualitas lebih baik. Efisiensi audit menjadikan audit delay semakin pendek karena semakin panjang tenure dari seorang auditordan pemahaman terhadap bisnis klien semakin tinggi. Sehingga apabila perusahaan diaudit oleh auditor spesialis maka audit delay akan lebih pendek. Maka, berdasarkan uraian diatas hipotesis pada penelitian ini adalah sebagai berikut.

$\mathrm{H}_{3}$ : Spesialisasi auditor memperkuat pengaruh negatif audit tenure pada audit delay.

Tingkat kesehatan perusahaan terlihat dari kondisi keuangan perusahan. Auditor spesialisasi memiliki pengetahuan lebih pada suatu industri tertentu, sehingga dapat memahamai karakteristik pada perusahaan secara lebih 
komperhensif (Owusu-Ansah, 2000). Kemampuan untuk mendeteksi kesalahan dapat lebih baik dilakukan oleh auditor spesialis (Johnson et al., 2002).

Kecenderungan dimana perusahaan dalam kondisi kesulitan keuangan akan memiliki resiko audit yang lebih tinggi. Dengan adanya auditor spesialis dalam perusahaan dianggap mampu mendeteksi kesalahan. Maka adanya spesialisasi auditor didalam perusahaan yang mengalami financial distress dianggapakan mampu meminimalisir terjadinya audit delay. Berdasarkan penelitian terdahulu dan uraian diajukan hipotesis sebagai berikut.

$\mathrm{H}_{4}$ : Spesialisasi auditor memperlemah pengaruh positif financial distress pada audit delay.

\section{METODE PENELITIAN}

Desain penelitian adalah pedoman atau prosedur serta teknik dalam perencanaan penelitian yang berguna sebagai panduan untuk membangun strategi yang menghasilkan model penelitian. Desain penelitian yang digunakan dalam penelitian.

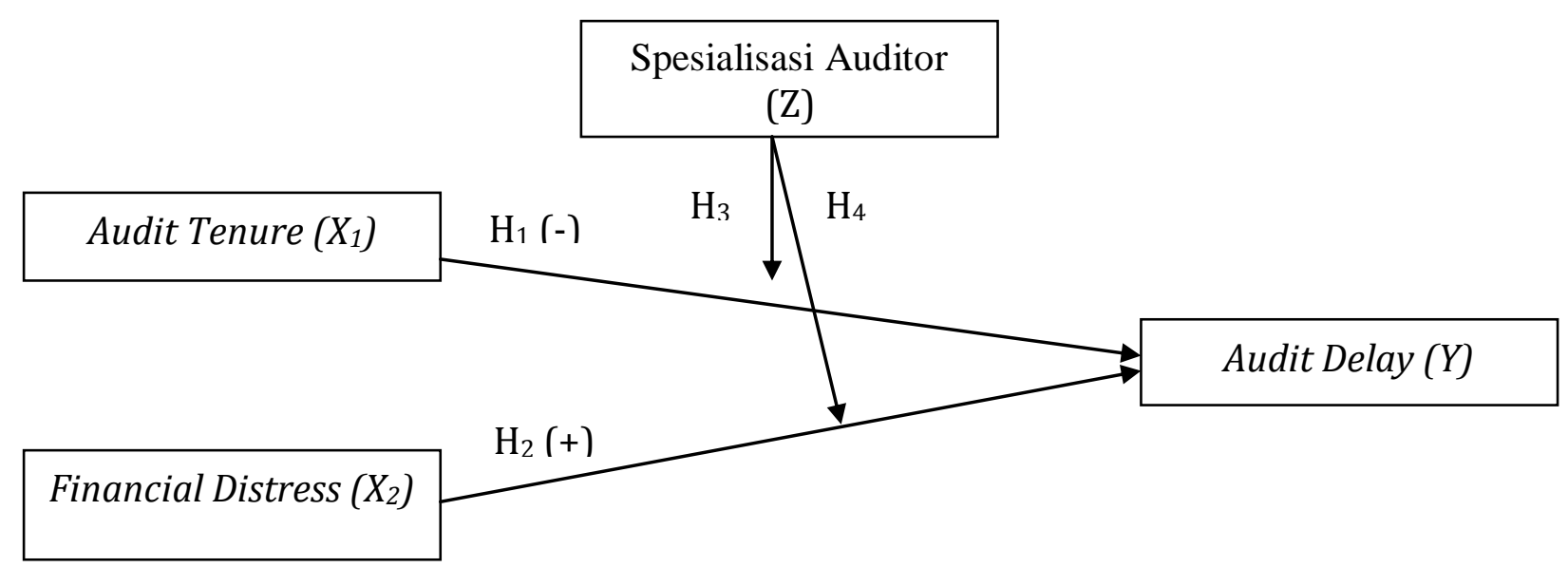

Gambar 1. Desain Penelitian 
Ni Made Dwi Candra Sawitri dan I Ketut Budiartha. Pengaruh ...

Penelitian ini terbatas pada perusahaan pertambangan yang terdaftar di Bursa Efek Indonesia (BEI) pada tahun 2012-2016 dan telah mempublikasikan laporan keuangan auditan melaui situs www.idx.co.id.. Objek dalam penelitian ini adalah audit tenure dan financial distress dan melalui spesialisasi auditor sebagai variabel pemoderasi. Penyampelan atas responden dilakukan secara purposive sampling. Sampel yang dipilih memiliki kriteria 1) Perusahaan pertambangan yang terdaftar di Bursa Efek Indonesia (BEI) tahun 2012-2016. 2) Perusahaan pertambangan yang konsisten mempublikasikan laporan keuangan tahun 20122016. 3) Perusahaan memiliki periode akhir tahun buku per 31 Desember.

Jenis data yang gunakan dalam penelitian ini adalah data kuantitatif dan kualitatif. Data kualitatif pada penelitian ini yaitu perusahaan pertambangan yang tercatat di Bursa Efek Indonesia (BEI) tahun 2012-2016. Data kuantitatif penelitian ini adalah laporan keuangan perusahaan pertambangan yang terdaftar di BEI tahun 2012-2016. Sumber data dalam penelitian ini adalah data sekunder. Metode pengumpulan data yang digunakan dalam penelitian ini adalah dengan menggunakan metode observasi non partisipan.

Variabel independen dalam penelitian ini adalah Audit tenure $\left(X_{1}\right)$ dan Financial distress $\left(X_{2}\right)$. Audit Tenure, tenure adalah lamanya masa perikatan Kantor Akuntan Publik (KAP) dalam memberikan jasa audit terhadap kliennya. Audit Tenure diukur dengan cara menghitung jumlah tahun perikatan perusahaan yang menggunakan jasa KAP yang melakukan perikatan audit terhadap auditee, tahun pertama perikatan dimulai dengan angka 1 dan ditambah dengan satu untuk tahun-tahun berikutnya. Apabila terjadi pergantian KAP maka dihitung dimulai 
dengan angka 1 untuk tahun pertama perikatan. Financial distress merupakan keadaan dimana keuangan perusahaan mengalami penurunan dikarenakan adanya berita buruk dalam laporan keuangan. Financial distress diukur dengan Debt to Asset Ratio (DAR) karena rasio debt to asset menunjukkan seberapa besar keseluruhan hutang dapat dijamin oleh keseluruhan harta yang dimiliki oleh perusahaan. Penghitungan terhadap financial Distress ini rumus :

$$
\mathrm{DAR}=\frac{\text { rata }- \text { ratatotalutang }}{\text { rata }- \text { ratatotalaset }} \times 100 \%
$$

Variabel dependen (Y) dalam penelitian ini audit delay perusahaan pertambangan.Audit delay merupakan waktu penyelesaian audit yang dihitung dari tanggal tutup tahun buku terakhir hingga tanggal laporan auditor independen. Audit delay dihitung dari jumlah hari tanggal tutup tahun buku perusahaan pada 31 Desember hingga tanggal penandatanganan laporan audit independen.

Variabel Moderating (Z) variabel yang mempengaruhi hubungan antara variabel dependen dan independen (memperkuat atau memperlemah). Dimana variabel moderating dalam penelitian ini adalah spesialisasi auditor. Variabel spesialisasi auditor diukur dengan jumlah perusahaan pertambangan yang diaudit oleh auditor/KAP yang sama dibagi dengan jumlah total perusahaan pertambangan yang terdaftar di BEI dikalikan 100\%. Apabila proporsinya lebih dari $15 \%$ maka dinyatakan auditor tersebut memiliki spesifikasi industri begitu pula sebaliknya (Knechel et al. 2007).Selanjutnya hasil pengukuran dikategorikan dengan menggunakan variabel dummy dimana perusahaan yang diaudit oleh auditor spesialis diberi kode 1 dan perusahaan yang tidak diaudit oleh auditor spesialis diberi kode 0 . 
Penelitian ini melakukan uji interaksi untuk menguji variabel moderating spesialisasi auditor dengan menggunakan Moderated Regression Anlyisis (MRA). Model regresi dalam penelitian ini ditunjukan dengan persamaan sebagai berikut.

$$
Y=\alpha+\beta_{1} X_{1}+\beta_{2} X_{2}+\beta_{3} Z+\beta_{4} X_{1} Z+\beta_{5} X_{2} Z+e
$$

\section{Keterangan :}

$$
\begin{array}{ll}
\mathrm{Y} & =\text { Audit delay } \\
\alpha & =\text { konstanta } \\
\beta 1-\beta 5 & =\text { koefisien } \\
\mathrm{X}_{1} & =\text { Audit tenure } \\
\mathrm{X}_{2} & =\text { Financial distress } \\
\mathrm{Z} & =\text { Spesialisasi Auditor } \\
\mathrm{e} & =\text { Standar Error }
\end{array}
$$

\section{HASIL DAN PEMBAHASAN}

Data sekunder yang diperoleh kemudian dipilih berdasarkan kriteria - kriteria yang telah ditentukan. Berdasarkan sumber yang diperoleh 42 perusahaan pertambangan yang terdiri atas beberapa sub sector diantaranya 24 sub sektor batu bara, 7 sub sektor minyak dan gas bumi, 9 sub sektor logam dan mineral lainnya, dan 2 sub sektor batu - batuan. Proses seleksi berdasarkan kriteria yang telah ditetapkan sisajikan dalam Tabel 1.

Tabel 1.

Proses Seleksi Sampel Berdasarkan Kriteria

\begin{tabular}{llc}
\hline No & \multicolumn{1}{c}{ Kriteria } & Jumlah sampel \\
\hline 1. & $\begin{array}{l}\text { Perusahaan pertambangan yang terdaftar di Bursa Efek Indonesia (BEI) pada } \\
\text { tahun 2012-2016. }\end{array}$ & 42 \\
2. & $\begin{array}{l}\text { Perusahaan pertambangan yang tidak mempublikasikan laporan keuangan } \\
\text { secara konsisten pada tahun 2012-2016. }\end{array}$ & $(10)$ \\
3. & Perusahaan yang tidak memiliki periode akhir tahun buku per 31 Desember. & $(0)$ \\
$\mathbf{4}$ & Data Outlayer. & $(7)$ \\
& Jumlah sampel akhir. & 25 \\
& Tahun pengamatan. & 5 \\
& Jumlah pengamatan. & 125 \\
\hline & Sumber : data diolah, 2017
\end{tabular}


Statistik deskriptif dalam penelitian ini disajikan untuk memberikan gambaran mengenai karakteristik variabel penelitian antara lain minimum, maksimum, nilai rata-rata (mean), dan standar deviasi. Hasil statistik deskriptif penelitian ini dapat dilihat pada Tabel 2.

Tabel 2.

Hasil Analisis Statistik Deskriptif

\begin{tabular}{lrrrrr}
\hline & N & $\begin{array}{c}\text { Minimu } \\
\text { m }\end{array}$ & $\begin{array}{c}\text { Maximu } \\
\mathbf{m}\end{array}$ & \multicolumn{1}{c}{ Mean } & \multicolumn{1}{c}{$\begin{array}{c}\text { Std. } \\
\text { Deviation }\end{array}$} \\
\hline X1 & 125 & 1.00 & 5.00 & 2.2560 & 1.30077 \\
X2 & 125 & 1.14 & 187.50 & 43.6605 & 25.02070 \\
Z & 125 & .00 & 1.00 & .5840 & .49488 \\
Y & 125 & 39.00 & 274.00 & 75.0960 & 27.08542 \\
Valid N & 125 & & & & \\
$\quad$ (listwise) & & & & & \\
Sumber : data diolah 2017 & & & & &
\end{tabular}

Berdasarkan Tabel 2 diatas dapat dilihat nilai minimum audit tenure $\left(\mathrm{X}_{1}\right)$ adalah 1,00 dan nilai maksimum adalah 5,00. Nilai minimum sesuai dengan tabulasi data dimana perusahaan yang memiliki audit tenure 1,00 sebanyak 25 dan perusahaan yang memiliki nilai maksimum 5,00 sebanyak 10. Mean untuk audit tenure adalah 2,2560 , berarti rata-rata perusahaan melakukan perikatan dengan sebuah KAP selama 2 tahun 3 bulan. Standar deviasinya 1,30077, hal ini berarti berarti terjadinya penyimpangan audit tenure terhadap nilai rata-rata yaitu sebesar 1,30077 .

Nilai minimum variabel financial distress (X2) adalah sebesar 1,14 dan nilai maksimum sebesar 187,50. Nilai minimum sesuai dengan tabulasi data perusahaan Cakra Mineral Tbk tahun 2014 dan niilai maksimum sesuai dengan tabulasi data perusahaan Bumi Resources Tbk tahun 2016. Mean variabel financial distress 43,6605, hal ini berarti rata-rata DAR perusahaan sampel adalah 
Ni Made Dwi Candra Sawitri dan I Ketut Budiartha. Pengaruh ...

$43,6605 \%$ setiap 43,6605 satuan utang dijamin oleh 100 satuan asset. Standar deviasinya sebesar 25,02070, maka terjadi penyimpangan financial distress terhadap nilai rata-ratanya sebesar 25,02070.

Variabel audit delay (Y) memiliki nilai minimum sebesar 39,00 dan nilai maksimum sebesar 274,00. Nilai minimum sesuai dengan tabulasi data perusahaan Baramulti Suksessarana Tbk tahun 2016 dan perusahaan Elnusa Tbk tahun 2016. Nilai maksimum sesuai dengan tabulasi data perusahaan Bumi Resources Tbk tahun 2015. Mean variabel audit delay sebesar 75,0960, hal ini berarti bahwa rata-rata perusahaan pertambangan mempublikasikan laporan keuangan selama 75 hari dari tanggal tutup tahun buku 31 desember sampai penandatanganan laporan audit oleh auditor. Sesuai dengan aturan yang ditentukan oleh OJK yakni Peraturan OJK Nomor 29/POJK.04/2016. yaitu maksimal 90 hari setelah berakhirnya tahun laporan keuangan akhir tahun 31 Desember berarti rata-rata perusahaan pertambangan yang terdaftar di BEI, melaporkan atau mempublikasikan laporan keuangan auditan tidak melewati batas waktu yang telah ditentukan. Standar deviasinya adalah sebesar 27,08542, hal ini berarti terjadinya penyimpangan audit delay terhadap nilai rata-ratanya sebesar 27,08542 .

Nilai minimum spesialisasi auditor $(\mathrm{Z})$ adalah 0,00 dan nilai maksimum adalah 1,00. Nilai minimum sesuai dengan tabulasi data dimana perusahaan yang memiliki spesialisasi auditor 0,00 sebanyak 14 dan perusahaan yang memiliki nilai maksimum 1,00 sebanyak 21. Mean untuk spesialisasi auditor adalah 0,5840, hal ini Perusahaan manufaktur yang menjadi sampel dalam melakukan 
pengauditan menggunakan KAP yang tergolong pada auditor spesialisasi sebanyak 58\%, atau setengah dari jumlah sampel menggunakan auditor spesialisasi dalam mengaudit laporan keuangan perusahaan mereka. Standar deviasinya 0,49488 , hal ini berarti berarti terjadinya penyimpangan spesialisasi auditor terhadap nilai rata-rata yaitu sebesar 0,49488.

Uji normalitas dilakukan untuk mengetahui apakah dalam model regresi memiliki distribusi normal atau tidak. Uji normalitas dapat dilakukan dengan menggunakan uji kolmogorov-smirnov. Hasil uji normalitas dapat dilihat pada Tabel 3.

Tabel 3.

Uji Normalitas

\begin{tabular}{llr}
\hline \multicolumn{1}{c}{ One-Sample Kolmogorov-Smirnov Test } \\
& & $\begin{array}{c}\text { Unstandardized } \\
\text { Residual }\end{array}$ \\
$\mathrm{N}$ & & 125 \\
Normal Parameters & Mean & $0 \mathrm{E}-7$ \\
& Std. Deviation & .27561800 \\
Most Extreme Differences & Absolute & .097 \\
& Positive & .097 \\
& Negative & -.074 \\
Kolmogorov-Smirnov Z & & 1.082 \\
Asymp. Sig. (2-tailed) & & .192 \\
\hline Sumber $:$ data diolah 2017 & &
\end{tabular}

Berdasarkan tabel 3 tersebut menunjukan bahwa nilai Asymp.Sig.(2-tailed) sebesar 0,192 > (0,05), sehingga dapat disimpulkan bahwa variabel dalam penelitian ini berdistribusi secara normal. Pendeteksian adanya multikolineritas dalam model regresi adalah terlihat dari nilai tolerance dan variance inflation factor (VIF). Nilai tolerance lebih besar dari 10\% atau VIF kurang dari 10, maka model dikatakan bebas dari gejala multikoleniaritas. Berdasarkan hasil pengujian, dapat dilihat bahwa nilai tolerance semua variabel lebih besar dari $10 \%$ dan nilai VIF semua variabel kurang dari 10. Dengan hasil tersebut dapat disimpulkan 
Ni Made Dwi Candra Sawitri dan I Ketut Budiartha. Pengaruh ...

bahwa data dalam penelitian ini tidak terjadi gejala multikolinearitas. Nilai Durbin-Watson (DW test) yang dihasilkan adalah sebesar 1,843. nilai dU untuk jumlah data $(n)=125$ dan jumlah variabel bebas $(\mathrm{k})=3$ serta $\alpha=5 \%$ diperoleh angka $d l=1,6592$ dan $d u=1,7574$, sehingga hasil uji autokorelasi adalah du $<$ DW $<$ 4-du yaitu $1,7574<1,843<2,408$. dengan hasil tersebut terlihat bahwa data yang digunakan terbebas dari autokorelasi.

Uji heteroskedastisitas bertujuan untuk menguji apakah dalam model regresi terjadi ketidaksamaan hasil dari residual satu ke pengamatan yang lain. Berdasarkan pengujian yang dilakukan, diperoleh tingkat signifikansi berada diatas 0,05 , dapat disimpulkan bahwa model regresi tidak mengandung adanya heteroskedastisitas.

Tabel 4.

Uji Kelayakan Model (uji F)

\begin{tabular}{|c|c|c|c|c|c|c|}
\hline Model & & $\begin{array}{l}\text { Sum of } \\
\text { Squares }\end{array}$ & df & $\begin{array}{c}\text { Mean } \\
\text { Square }\end{array}$ & $\mathbf{F}$ & Sig. \\
\hline \multirow[t]{3}{*}{1} & Regression & 1.306 & 5 & .261 & 3.300 & $.008^{\mathrm{b}}$ \\
\hline & Residual & 9.420 & 119 & .079 & & \\
\hline & Total & 10.726 & 124 & & & \\
\hline \multicolumn{7}{|c|}{ a. Dependent Variable: LnY } \\
\hline \multicolumn{7}{|c|}{ b. Predictors: (Constant), X2_Z, X2, LnX1, LnX1_Z, Z } \\
\hline
\end{tabular}

Berdasarkan hasil perhitungan uji $\mathrm{F}$ pada Tabel 4 menunjukan nilai dari uji F dalam penelitian sebesar 3,300 dan tingkat signifikansi uji $\mathrm{F}$ sebesar 0,008< 0,05 , maka model regresi yang digunakan layak.

Tabel 5.

Hasil Uji Koefisien Determinasi $\left(\mathbf{R}^{2}\right)$

\begin{tabular}{|c|c|c|c|c|}
\hline Mode & $\mathbf{R}$ & R Square & $\begin{array}{c}\text { Adjusted R } \\
\text { Square }\end{array}$ & $\begin{array}{l}\text { Std. Error of } \\
\text { the Estimate }\end{array}$ \\
\hline $\begin{array}{l}1 \\
\text { a. Pred } \\
\text { b. Depe }\end{array}$ & $\begin{array}{l}.349^{\mathrm{a}} \\
\text { (Consta } \\
\text { Variabl }\end{array}$ & $\begin{array}{l}.122 \\
\mathrm{X} 2 \_Z, \mathrm{X} 2, \\
\mathrm{LnY}\end{array}$ & K1, LnX1_Z, Z & .2813487 \\
\hline
\end{tabular}


Berdasarkan hasil uji koefisien determinasi pada Tabel 5 menunjukkan nilai $R$ square model sebesar 0,122 artinya sebesar 12,2 persen variabel audit delay yang dipengaruhi oleh audit tenure, financial distress dan spesialisasi auditor dan sisanya 87,8 persen dijelaskan oleh variabel lain diluar model seperti profitabilitas, leverage, ukuran perusahaan, pergantian auditor, ukuran KAP, opini auditor dan struktur kepemilikan saham.

Tabel 6.

Hasil Moderated Regression Analysis

\begin{tabular}{|c|c|c|c|c|c|}
\hline \multirow[t]{2}{*}{ Model } & & \multicolumn{2}{|c|}{$\begin{array}{l}\text { Unstandardized } \\
\text { Coefficients }\end{array}$} & \multirow{2}{*}{$\begin{array}{l}\text { Standardized } \\
\text { Coefficients } \\
\text { Beta }\end{array}$} & \multirow[t]{2}{*}{ Sig. } \\
\hline & & B & $\begin{array}{l}\text { Std. } \\
\text { Error }\end{array}$ & & \\
\hline 1 & (Constant) & 4.174 & .079 & & .000 \\
\hline & LnX1 & -.080 & .072 & -.158 & .272 \\
\hline & $\mathrm{X} 2$ & .004 & .001 & -.426 & .001 \\
\hline & $\mathrm{Z}$ & .099 & .122 & .167 & .420 \\
\hline & LnX1_Z & .094 & .092 & .186 & .307 \\
\hline & X2_Z & -.005 & .002 & .344 & .027 \\
\hline
\end{tabular}

Sumber : data diolah 2017

Berdasarkan Tabel 6 Persamaan regresi yang dihasilkan melalui moderated regresion analysis (MRA) adalah sebagai berikut.

$Y=4,174-0,080 X_{1}+0,004 X_{2}+0,099 Z+0,094 X_{1} Z-0,005 X_{2} Z+e$

Berdasarkan persamaan regresi diatas diketahui nilai konstanta 4,174 memiliki arti apabila audit tenure, financial distress, spesialisasi auditor sama dengan dengan nol, maka audit delay sebesar positif 4,174. Nilai koefisien regresi audit tenure sebesar -0,080 memiliki arti apabila audit tenure naik sebesar satu satuan, maka audit delay turun sebesar negatif 0,080 satuan dengan asumsi variabel lainnya sama dengan nol. Nilai koefisien regresi financial distress sebesar 0,004 memiliki arti apabila financial distress naik sebesar satu satuan, maka audit 
Ni Made Dwi Candra Sawitri dan I Ketut Budiartha. Pengaruh ...

delay naik sebesar positif 0,004 satuan dengan asumsi variabel lainnya sama dengan nol.

Nilai koefisien regresi spesialisasi auditor sebesar 0,099 memiliki arti apabila spesialisasi auditor naik sebesar satu satuan, maka audit delay turun sebesar positif 0,099 satuan dengan asumsi variabel lainnya sama dengan nol. Nilai koefisien moderat audit tenure spesialisasi auditor sebesar 0,094 mengindikasikan bahwa setiap interaksi audit tenure dengan spesialisasi auditor meningkat satu satuan akan mengakibatkan audit delay naik sebesar positif 0,094. Nilai koefisien moderat financial distress dengan spesialisasi auditor sebesar 0,005 mengindikasikan bahwa setiap interaksi financial distress dengan spesialisasi auditor meningkat satu satuan akan mengakibatkan penurunan pada audit delay sebesar negatif 0,005 .

Berdasarkan Tabel 6 diperoleh nilai signifikansi 0,272>0,05, dapat disimpulkan bahwa $\mathrm{H}_{1}$ ditolak yang berarti audit tenure tidak berpengeruh terhadap audit delay. Hasil penelitian ini sependapat dengan penelitian Yulia dan Rasmini (2016), Rustiarini dan mita (2013), Lased dan Sutaryo (2014) dan Zulfikar (2015) yang menunjukan hasil bahwa tidak adanya pengaruh audit tenure terhadap audit delay. Masa perikatan yang panjang dianggap dapat mengurangi indepedensi dari auditor. Berkurangnya independensi dapat menurunkan nilai kualitas audit. Hal tersebut dapat terjadi dikarenakan adanya kedekatan antar auditee dengan auditor dapat menyebabkan auditor membenarkan kecurangankecurangan yang terjadi. 
Berdasarkan Tabel 6 diperoleh nilai signifikansi sebesar 0,001<0,05, maka dapat disimpulkan $\mathrm{H}_{1}$ diterima yang berarti financial distress berpengeruh terhadap audit delay. Hasil penelitian ini sependapat dengan penelitian Muliantari dan Yenni (2017), Yulia dan Rasmini (2016) yang menunjukan hasil bahwa adanya pengaruh positif financial distress terhadap audit delay.

Audit delay akan bertambah ketika laporan keuangan mengalami proses penundaan. Adanya penundaan ini terjadi karena terdapat berita buruk dalam laporan keuangan. Financial Distress merupakan kabar buruk pada laporan keuangan. Berita buruk pada perusahaan dapat menyebabkan audit delay semakin panjang, karena manajemen perusahaan sengaja mengurangi berita buruk pada laporan keuangan perusahaan. Financial distress juga dapat digambarkan keadaan dimana penurunan keuangan perusahaan yang terjadi sebelum kebangkrutan atau likuidasi. Kondisi financial distress pada perusahaan dapat meningkatkan risiko audit. Dengan meningkatnya risiko audit, maka auditor harus melakukan pemeriksaan risiko dan menunda proses audit yang dapat berdampak terhadap bertambahnya audit delay.

Berdasarkan Tabel 6 diperoleh nilai signifikasi 0,307>0,05 sehingga hipotesis ketigata dalam penelitian ini ditolak. Pada Tabel 6 variabel moderasi spesialiasi auditor tidak mampu memoderasi pengaruh audit tenure dengan audit delay.

Hasil penelitian ini sependapat dengan penelitian Rosyidi (2017) dan Rahayu (2012) yang menunjukan hasil spesialisasi auditor tidak memoderasi hubungan audit tenure pada audit delay. Auditor spesialisasi tidak dapat menjaga 
Ni Made Dwi Candra Sawitri dan I Ketut Budiartha. Pengaruh ...

independensi dalam melaksanakan audit. Auditor tidak menggunakan kemampuan professional dalam melaksanakan proses auditnya karena adanya kepentingan pribadi dari klien menjadi salah satu faktor yang memperpanjang audit delay. Adanya kepentingan pribadi tersebut dapat menyebabkan terganggunya independensi dari auditor dan dapat membenarkan kecurangan-kecurangan terjadi.

Berdasarkan Tabel 6 diperoleh nilai signifikasi 0,027 $<0,05$ maka hipotesis keempat diterima. Pada Tabel 6 dapat spesialiasi auditor memperlemah hubungan financial distress dengan audit delay.

Perusahaan yang mengalami financial distress (kesulitan keuangan) cenderung akan terlambat untuk menyelesaikan dan mempublikasikan laporan keuangannya dikarenakan seorang auditor melakukan pemeriksaan terhadap risiko yang akan dialami oleh perusahan, sehingga menghambat proses audit. Auditor dengan spesialisasi industri memiliki pengetahuan yang lebih pada industri tertentu dan dapat lebih mudah dalam memahami karakteristik klien pada suatu industri (Owusu-Ansah, 2000). Kemampuan lebih tersebut dapat meningkatkan kemampuan auditor dalam mendeteksi kesalahan pada laporan keuangan, sehingga meminimalisir terjadinya keterlambatan dalam mempublikasikan laporan keuangan.

Berdasarkan pembahasan yang telah diuraikan diatas, terdapat beberapa implikasi dalam bidang akademisi dan penelitian selanjutnya serta para praktisi untuk: a). Bagi para akademisi; hasil penelitian ini diharapkan dapat memberikan kontribusi dalam pengembangan teori, terutama dalam bidang akuntansi mengenai faktor-faktor yang mempengaruhi audit delay dan dapat digunakan sebagai acuan 
untuk riset-riset mendatang.b). Bagi pihak regulator; hasil penelitian ini diharapkan dapat menjadi pertimbangan dalam merancang regulasi dan kebijakan mengenai ketepatan waktu penyampaian laporan keuangan. c). Bagi para praktisi penelitian ini dapat menjadi referensi auditor dan KAP untuk meningkatkan efektivitas dan efisiensi audit sehingga meminimalisir terjadinya audit delay, sehingga penyampaian laporan keuangan dapat dipublikasikan secara tepat waktu.

\section{SIMPULAN}

Berdasarkan hasil pembahasan dapat diambil simpulan sebagai berikut. 1) Audit tenure tidak berpengaruh pada audit delay. 2) Financial Distress berpengaruh positif terhadap audit delay. 3) Spesialisasi auditor tidak mampu memoderasi pengaruh audit tenure terhadap audit delay. 4) Spesialisasi auditor mampu memoderasi pengaruh financial distress terhadap audit delay. Berdasarkan penjelasan yang diberikan saran bahwa penelitian selanjutnya disarankan penelitian selanjutnya disarankan menggunakan data terbaru serta dapat memilih jenis perusahaan selain perusahaan pertambangan untuk dapat melihat pengaruh variabel bebas lainnya terhadap audit delay. Bagi penelitian selanjutnya diharapkan menggunakan variabel dependen lain yang mempengaruhi audit delay misalnya profitabilitas, leverage, ukuran perusahaan, pergantian auditor. Penelitian selanjutnya dapat melakukan pengujian menggunakan variabel pemoderasi lain misalnya ukuran perusahaan, atau dapat menggunakan uji mediasi. Bagi pihak manajemen perusahaan penelitian ini dapat dijadikan acuan dalam mengidentifikasi faktor-faktor yang berpengaruh terhadap audit delay, dengan demikian dapat lebih mempersingkat waktu penyampaian laporan 
keuangan sesuai dengan peraturang yang telah ditetapkan oleh Otoritas Jasa Keuangan (OJK).

\section{REFERENSI}

Agus, Narayana Dewa Gede dan Yadnyana I Ketut. 2017. Pengaruh Struktur Kepemilikan, Financial Distress, dan Audit Tenure Pada Ketepatwaktuan Publikasi Laporan Keuangan. E-jurnal Akuntansi Universitas Udayana. 8(3). Hal 2085-2114.

Chen, C-Y., Lin, C-J \& Lin Y-C. 2004. Audit Partner Tenure, Audit Firm Tenure and Discretionary Accrual : does long auditor tenure impair earning quality?. Working Paper. Hong Kong Uniersity of Science and Technology.

Craswell, A.T., Francis, J.R. and Taylor. S.L. (1995). Auditor brand name reputations and industry specializations. Journal of Accounting and Economics, 20, 297-322.

Dao, M., \& Trung Pham. (2014). Audit Tenure, Auditor Specialization, and Report Lag. Managerial Auditing Journal Vol.29 No.6, 490-515

Dewi, Karina. 2013. Analisis Faktor-Faktor yang Mempengaruhi Ketepatan Waktu dan Audit Delay Penyampaian Laporan Keuangan (Studi Empiris pada Perusahaan Manufaktur yang Terdaftar di BEI Periode 2007-2011). Skripsi. Fakultas Ekonomi Universitas Diponegoro, Semarang.

Febrianty. 2011'Faktor-Faktor Yang Berpengaruh Terhadap Audit Delay Perusahaan Sektor Perdagangan yang Terdaftar di BEI Periode 2007-2009”. Jurnal ekonomi dan Informasi Akuntansi (Jenius). Vol 1, No. 3;September 2011.

Fitriyani, C. A., P. Purnamasari dan M. Maemunah. 2015. Pengaruh Tenure Audit, Ukuran KAP Dan Kompleksitas Operasi Perusahaan Terhadap Audit Report Lag (Studi Kasus Pada Perusahaan Consumer Goods Yang Terdaftar Di Bursa Efek Indonesia Periode 2010-2014). Prosiding Akuntansi. Universitas Islam Bandung. 
Geiger, Marshall A., \& Raghunandan, K., 2002. "Auditor Tenure and Audit Reporting Failures", Auditing: A Journal of Practice \& Theory, Vol. 21, No. 1, March 2002, pp. 67-78.

Giri, Efraim F. 2010. Pengaruh Tenure Kantor Akuntan Publik (KAP) dan Reputasi KAP terhadap Kualitas Audit: Kasus Rotasi Wajib Auditor di Indonesia. Simposium Nasional Akuntansi XIII . Purwokerto.

Habib, Ahsan \&Md. B. U. Bhuiyan. 2011. Audit Firm Industry Specialization and Audit Report Lag. Journal of Internasional Accounting, Auditing,and Taxation Vol.20, 32-44.

Halim, Varianada, 2000, Faktor-faktor yang Mempengaruhi Audit Delay: studi empiris pada perusahaan-perusahaan di Bursa Efek Jakarta, Jurnal Bisnis dan Akuntansi, Vol. 2 No. 1, p. 63-75

Hersugondo, \& Kartika , A. (2013). Prediksi Probabilitas Audit Delay dan Faktor Determinannya. Jurnal Ekonomi - Manajemen - AkuntansiISSN 0853-8778.

Hogan, C.E. \& Jeter, D.C. (1999). Industry Specialization by Auditors. A Journal of Practice \& Theory, 18, 1-17.

Ika, S.R. dan N.A.M. Ghazali. 2012. Audit Committee Effectiveness and Timeliness of Reporting: Indonesian Evidence. Managerial Auditing Journal 27(4): 403-424

Jensen, C., \& Meckling, H. (1976). Theory of the Firm: Managerial Behavior, Agency Costs and Ownership Structure. Journal of Financial Economics, 3, 305-360. http://doi.org/10.1016/0304-405X(76)90026-X

Johnson, V.E, Khurana, I.K. and Reynold, J.K. (2002) Audit-firm tenure and the quality of financial reports; Contemporary Accounting Research 19(4) 637660.

Julien, R.F. 2013. Pengaruh Tingkat Profitabilitas, Financial Distress, dan Pelaporan Rugi Bersih Klien Terhadap Audit Report Lag perusahaan Manufaktur yang Terdaftar di Bursa Efek Indonesia. Skripsi Program Studi Akuntansi Universitas Lampung Bandar Lampung. 
Knechel, W. Robert and A. Vanstraelen. 2007. The Relationship between Auditor Tenure and Audit Quality Implied by Going Concern Opinions. Auditing: A Journal of Pravtice \& Theory, 26:113-131

Kwon, S.Y., C.Y. Lim, and M.S. Tan. "Legal Systems and Earning Quality: The Role of Auditor Industry Specialization." Auditing: A Journal o f Practice \& Theory 26, no. 2 (2007): 25-55.

Lase, Y dan Sutaryo. 2014. Pengaruh Karakteristik Auditor Terhadap Audit Delay Laporan Keuangan Pemerintah Daerah.Simposium nasional Akuntansi 17. Mataram.

Lee, H.-Y., Mande, V., \& Son, M. (2009). Do Lengthy Auditor Tenure and the Provision of Non-Audit Services by the External Auditor Reduce Audit Report Lags? International Journal of Auditing, 13(2), 87-104.

Mardyana, R. 2014. Effect of Good Corporate Governance, Financial Distress and Financial Performance on Timeliness of Financial Statements Reporting. Journal International Program in Accounting, Economics Business Faculty. $1(3)$.

Muliantari, Indah Ayu Ni Putu dan Yenni Latrini Made. 2017. Ukuran Perusahaan Sebagai Variabel Pemoderasi Pengaruh Profitabilitas dan Financial Distress Terhadapa Audit Delay Pada Perusahaan Manufaktur. Jurnal Akuntansi Universitas Udayana. Vol.20.3.Hal:1875-1903

Owusu-Ansah, S. L. 2006. Timeliness of Corporate Annual Financial Reporting in Greece. European Accounting Review Vol. 15 No.2 , 273-287.

Peraturan Otoritas Jasa Keuangan Nomor 29/POJK.04/2016 Tentang Laporan Tahunan Emiten atau Perusahaan Publik.

Rahayu, Karina. 2012. Pengaruh Tenure Audit Terhadap Audit Report Lag dengan Spesialisasi Auditor sebagai Variabel Pemoderasi : Studi Pada Bank Umum Konvensional di Indonesia Tahun 2008-2010. Skripsi Universitas Indonesia - Jakarta

Ratnaningsih dan Dwirandra. 2016. "Spesialisasi Auditor Sebagai Variabel Pemoderasi Pengaruh Audit Tenure Dan Pergantian Auditor Pada Audit Delay”. E-Jurnal Akuntansi Universitas Udayana.Vol 16.1.Hal:18-44 
Rohami Shafie , Hussin, W.N., Yusof, M.A. \& Hussain, M.H., 2009. "Audit Firm Tenure and Auditor Reporting Quality: Evidence in Malaysia". International Business Research. Vol. 2.(2): p.99- 109.

Rosyidi, Ma:ruf. 2017. Pengaruh Audit Tenure, Tingkat Solvabilitas, Terhadap Audit Delay Dengan Spesialisasi Auditor Sebagai Variabel Pemoderasi. Skripsi Sarjana Akuntansi pada Fakultas Ekonomi dan Bisnis Universistas Muhammaddiyah Surakarta.

Rustiarini, Ni Wayan dan Ni Wayan Mita Sugiarti. 2013. Pengaruh Karakteristik Auditor, Opini Audit, Audit Tenure, Pergantian Auditor pada Audit Delay. Jurnal Ilmiah Akuntansi dan Humanika.Vol 2, No 2.

Saleh, R dan Susilowati. 2004. "Studi Empiris Ketepatan Waktu Pelaporan Keuangan Perusahaan Manufaktur di Bursa Efek Jakarta". Jurnal Bisnis Strategi. Vol.13. h. 67-80.

Solomon, I., Shields, M. D., \& Whittington, O. R. (1999). What Do IndustrySpecialist Auditors

Wiguna, Karina Rahayu. 2012. Pengaruh Tenure Audit terhadap Audit Report Lag dengan Spesialisasi Industri Auditor Sebagai Variabel Pemoderasi: Studi pada Bank Umum Konvensional di Indonesia Tahun 2008-2010. Skripsi Universitas Indonesia.

Yulia, Hartanti Praptika Putu dan Rasmini Ketut. 2016. Pengaruh Audit Tenure, Pergantian Auditor Dan Financial Distress Pada Audit Delay Pada Perusahaan Consumer Goods. E-jurnal Akuntansi Universitas Udayana. Vol 15, No.3. Hal:2052-2081

Zulfikar. 2015. Faktor-Faktor Yang Berpengaruh Terhadap Audit Report Lag. Jurnal Ilmiah Universitas Bakrie, 3(3). 